\title{
Bactericidal Cotton Fabrics Modified By Silver and Copper Nanoparticles: Optical Spectra, Structures, Electrical Resistance
}

\author{
Anna Eremenko ${ }^{1 *}$, Irina Petrik ${ }^{1}$, Natalia Smirnova ${ }^{1}$, Liudmyla Romanenko ${ }^{2}$, Elena Surmasheva ${ }^{2}$, Gali- $^{1}$ \\ na Korchak ${ }^{2}$, Oksana Tananaiko ${ }^{3}$, Mykola Ishchenko ${ }^{3}$
}

${ }^{1}$ Chuiko Institute of Surface Chemistry of NAS of Ukraine, 17 General Naumov str, Kyiv 03164, Ukraine

${ }^{2}$ Marzeev Institutes of Hygiene and Medical Ecology of NAMS of Ukraine, 50 Popudrenko str, Kyiv 02660, Ukraine

${ }^{3}$ Taras Shevchenko National University, 60 Volodymyrska str, Kyiv 01001, Ukraine

*Corresponding author: Anna Eremenko, Chuiko Institute of Surface Chemistry of NAS of Ukraine, 17 General Naumov str, Kyiv 03164,Ukraine, Tel: 8044 4429698; E-mail: annaerem@ukr.net

\begin{abstract}
The bactericidal activity, optical spectra, electron-microscopic images and electrical resistance of cotton textile modified with bimetallic silver/copper nanoparticles (Ag/CuNPs) against the series of the microorganisms (Escherichia coli, Staphylococcus aurous, and Pseudomonas aeruginosa) are studied. NPs' modified fabrics were produced by the developed by us method of soft heat treatment of tissue impregnated with silver and copper ions and characterized by the Diffusion-Reflectance Spectra (DRS), SEM, electrical resistance and the flame atomic absorption spectroscopy (FAAS) methods. Glucosidal residues of cotton participate in the reduction of silver ions to NPs, besides that fabrics contain $\mathrm{Ag} / \mathrm{Cu}_{2} \mathrm{O}$ (marked as $\mathrm{Ag} / \mathrm{Cu}$ NPs) nanosized compositions with the size of $20-60 \mathrm{~nm}$. The FAAS method has been used to determine the quantitative $\mathrm{Cu}: \mathrm{Ag}$ ratio within the $\mathrm{Ag} / \mathrm{CuNPs} /$ tissue structures. Dried bactericidal fabric does not have electrical conductivity indicating the absence of contact between particles, fixed in the tissue structure. The electrical resistance of fabrics decreases sharply upon wetting in the water or electrolyte solution. The increasing of the conductivity of the modified fabrics suggests the diffusion of corresponding metal ions from the surface of NPs in the tissue which may contribute to the direct interaction of bactericide agents with microbes in biological fluids. Obtained composites demonstrated excellent antimicrobial activity.
\end{abstract}

Received Date: December-16-2016

Accepted Date: December-27-2016

Published Date: December-31-2016

Citation: Eremenko.A., et al. Bactericidal cotton fabrics modified by silver and copper nanoparticles: optical spectra, structures, electrical resistance. (2016) J Imaging Sci 1(1): 42- 46.

DOI: $10.15436 / 2476-1869.16 .1272$

Keywords: Bactericidal cotton; Silver/copper; Nanoparticles; Surface Plasmon Resonance; Electrical resistance; E. coli; S. aureus; P. aeruginosa.

\section{Introduction}

Recently using of nanosized silver and copper particles as bactericides in the colloid state, on the silica or textile material surfaces is the subject of growing interest. Silver, as an antimicrobial agent, is capable to destroy the wide spectrum of antibiotic-resistance bacteria ${ }^{[1-3]}$. Copper in solid state and ionic form posses antimycotic and bactericide activity ${ }^{[4-6]}$. Modern understanding of the mechanism of inhibitory effect of silver on microorganisms is described with three basic processes: 1) the cell uptake of free silver ions, the interruption of ATP (adenosine triphosphate) production and DNA replication; 2) the formation of reactive oxygen species catalyzed by Ag ions and NPs; 3 ) direct destruction of the cell membrane by metal nanoparticles ${ }^{[7]}$. Besides copper and silver compounds demonstrate antiviral activity also ${ }^{[8]}$. Solid-state $\mathrm{Cu}_{2} \mathrm{O}$ disrupts host cell recognition by denaturing protein structures on viral surfaces, leading to the inactivation of viruses. Silver ions and $\mathrm{Ag}_{2} \mathrm{O}$ remarkably de- 
creased enzymatic activity of influenza viral proteins. Now the actual problems in the development of new antibacterial materials based on metal NPs are the following: simplifying and making cheaper of nanosized metal particles synthesis; stabilization of easy-oxidized NPs; reducing of their toxic effect. Bactericidal textile is widely used in hospitals, as bandaging material and clothing. For today many industrial soft goods are made with content of silver NPs (napkins, socks, linen etc). The ability of fabric firmly hold of silver NPs on the surface is very important. However silver has the toxic action on living organisms (maximum allowable concentration is $50 \mu \mathrm{g} / \mathrm{L})^{[3]}$. A copper is also toxic in big amounts. The risks of negative influence on an organism are minimal at external application of NPs. The introduction of $\mathrm{Cu}$ NPs in tissue to produce bactericidal agents is extremely promising also. There are known physical and chemical methods of modification of cotton and polymer materials requiring large inputs of energy, time and use of chemical reducing agents and stabilizers, long heating reaction mixtures, multi-stage drying and others ${ }^{[9,10]}$. Recently we reported effective and economical method of obtaining of the bactericidal bandage materials by impregnation of cotton fabric by aqueous solutions of silver and copper salts followed by a certain regime of heat treatment which can be implemented in the industry ${ }^{[11-13]}$. It does not require pre-treatment of fabrics, the use of chemical reducing agents, stabilizing agents and subsequent cleaning procedures. High antimicrobial properties of obtained composites were confirmed in experiments with a wide range of multidrug-resistant bacteria Escherichia coli, Enterobacter aerogenes, Proteus mirabilis, $K$. pneumoniae, $S$. aureus, Candida albicans yeasts and micromycetes, and activity remained high throughout 6 months. At the same time, all samples of fabrics containing only copper did not show the expressed bactericidal activity in particular probably due to the formation of the oxide layer around the copper NPs.

In this paper we study the bactericidal activity of cotton textile modified with bimetallic $\mathrm{Ag} / \mathrm{Cu}$ NPs in the wide range of silver and copper concentrations against a series of the microorganisms (Escherichia coli, Staphylococcus aureus and Pseudomonas aeruginosa) and examine the mobility of the nanoparticles within fabrics by measuring the electrical conductivity of obtained NP/tissue in the dry state and in a wet environment, as well as the quantitative ratio of $\mathrm{Cu}$ : $\mathrm{Ag}$ into the tissue structures using the flame atomic absorption spectroscopy method.

\section{Experimental}

To prepare the material modified with bimetallic nanoparticles $\mathrm{Ag} / \mathrm{Cu}$ we used aqueous solutions of silver nitrate and copper sulfate in a molar ratio $\mathrm{Ag}: \mathrm{Cu}=1: 1$ with the concentration of each of the salts in the range $0.0001 \div 0.1 \mathrm{~mol} / \mathrm{L}$. Cotton fabric gauze with density $36 \mathrm{~g} / \mathrm{m}^{2}$ and aqueous solutions of silver and copper salts have been used to produce bactericidal textile materials by impregnation. Impregnation time was 30 min. After that, tissue squeezed out and ironed at $200 \div 220^{\circ} \mathrm{C}$. Samples of tissue contained the ions of silver, copper and both ions $\mathrm{Ag}^{+} / \mathrm{Cu}^{2+}$ were prepared for comparison and dried during $24 \mathrm{~h}$ at room temperature on a paper substrate.

To measure the electrical resistance of the modified tissues, we used portable professional multifunction digital multimeter, HYELEC MS8229 (China). The electrode surface area was $1 \mathrm{~mm}^{2}$; the distance between electrodes during measurements was $1 \mathrm{~cm}$; the surface area of the fabric was $4,5 \mathrm{~cm}^{2}$.

For measuring of metal content within tissue by the method of flaming atom-absorption spectroscopy (FAAS) the samples of fabric modified with metal NPs were treated in $3 \mathrm{M}$ $\mathrm{HNO}_{3}$ during twenty-four hours. The volume of the sample was $25 \mathrm{ml}$. Content of metals in the obtained solution was measured by the flame atomic absorption spectrometry without additional sample pretreatment. A Carl Zeiss Jena AAS-N1 spectrometer equipped with hollow cathode lamps for copper and silver was used throughout this work. The equipment was operated at the standard conditions recommended by the manufacturer (wavelength: $324.7 \mathrm{~nm}(\mathrm{Cu}), 328.1 \mathrm{~nm}(\mathrm{Ag})$; lamp current 6.0 $\mathrm{mA}$; spectral slit width $0.2 \mathrm{~nm}$ ). The acetylene flow rate and the burner height were adjusted in order to obtain the maximum absorbance signal. Nebulizer flow rate was $3.0 \mathrm{~mL} \mathrm{~min}^{-1}$. On the results of the measuring the content of metals on the unit of the area of fabric has been calculated.

The diffusion-reflectance spectra (DRS) of the fabrics with NPs were registered by means of spectrophotometer Perkin Elmer Lambda Bio UV-vis with the integrating sphere of Labsphere RSA - PR- 20 in the range of wave's $200-1000 \mathrm{~nm}$.

Electron-microscopic images of obtained samples with metal NPs have been obtained at electron-scanning microscope FEI Inspect $\mathrm{S}$.

The bactericidal properties of the samples were studied in the following way. In melted and cooled to $45^{\circ} \mathrm{C}$ meat - peptonic agar the suspension of test organisms containing $10^{8} \mathrm{MK} /$ $\mathrm{ml}$ was introduced and the mixture was poured into a Petri dish. Test tissue samples with size $2 \times 2 \mathrm{~cm}$ were putted on the surface of agar. Pure tissue that does not contain antimicrobial components was considered as control. Cultivations of bacteria were placed in thermostat at $37^{\circ} \mathrm{C}$. The account of the results was performed after 24 - 48 hours for the largest area of growth retardation $(\mathrm{mm})$ microorganisms around the test sample. Experiments were repeated at least three times (subject to obtaining similar results). Antimicrobial activity against a number of pathogens has been defined as inhibition zone in $\mathrm{mm}$.

\section{Results and discussion}

When introducing metal ions in the structure of cotton fabrics by impregnation with solutions of metal salts and subsequent ironing at $200-220^{\circ} \mathrm{C}$, we took into account the fact that cotton has a structural unit of $\beta$-glucose residue $\left[\mathrm{C}_{6} \mathrm{H}_{7}(\mathrm{OH})_{3}\right]_{n}$, i.e. a polysaccharide. During heat treatment of fabrics low-molecular compounds, including alcohols, carboxylic acids, carbonyl derivatives, as well as hydrogen and $\mathrm{CO}$ are released, which are potential reducing agents of metal ions. Process of cellulose pyrolysis according to thermal analysis proceeds as follows. First, in a wide temperature range from 90 to $150^{\circ} \mathrm{C}$ is physically bound water evaporation. Active cellulose disintegration of mass loss only begins at $280^{\circ} \mathrm{C}$ and ending at about $370^{\circ} \mathrm{C}$. At different length cellulose heating, various chemical processes occur. We treat the modified tissues at the temperature and time regime when cotton destruction did not occur and the appearance reducing agents is apparently already happen.

DRS of tissue containing Ag NPs (Figure 1, spectra 2 and 3) contain a band of surface plasmon resonance (SPR) with a maximum in $427 \mathrm{~nm}$. This is evidence of the formation of sil- 
ver NPs on the surface of tissue. Correlation of SPR position with particle size allows us to evaluate their size as about 30 $\mathrm{nm}^{[11]}$. In the spectra of tissues that were dried in air without heat treatment, along with the Ag NPs band, absorption band of silver oxide $\operatorname{Ag}_{2} \mathrm{O}$ is present (spectra 4 and 5 in Figure 1). Presumably silver ions are recovered directly on the surface of the textile and visible light promotes charge transfer process in a complex which silver ions form with $\mathrm{OH}$ groups of glucose residues in the structure of cotton. The extinction coefficient $k$ of silver oxide compared to those for Ag NPs, is small[14,15], so the intensity of the band $470 \mathrm{~nm}$ is much lower than the intensity of the SPR band of Ag NPs at $430 \mathrm{~nm}$. The intensity of the absorption spectra 4 and 5 on Figure 1 are multiplied by a factor of 10. In the absorption spectra of tissues with Ag / Cu NPs after heat treatment, only the SPR band of Ag NPs with a maximum of $425 \mathrm{~nm}$ is observed (Figure. 2, spectra 1 and 2), while in the spectra of fabrics with both silver and copper ions (dried in the air), there are the bands of lower intensity with a maximum of 480 - $490 \mathrm{~nm}$ (Figure. 2 spectra 5 and 6). Ag/Cu/tissues had red-brownish color the tint of that appeared because of formation of copper protoxide and oxide which also have bactericide effect $^{[16]}$. We observed in optical absorption spectra of $\mathrm{Ag} / \mathrm{Cu}$ NPs the band corresponding to alloy, with maximum located between the SPR bands of Ag NPs (390 nm) and copper NPs (570 $\mathrm{nm})$. At the same time broadening and long-wave shift is typical for Ag NPs by increasing their size, but based on the assessment of the spectrum' form and calculated the size of the NPs we suppose the formation of bimetallic composition. Copper ions on the surface of fabrics (without heat treatment) are shown in a spectrum as a wide absorption band with a maximum of $800 \mathrm{~nm}$ (Figure. 2, sp. 3 and 4).

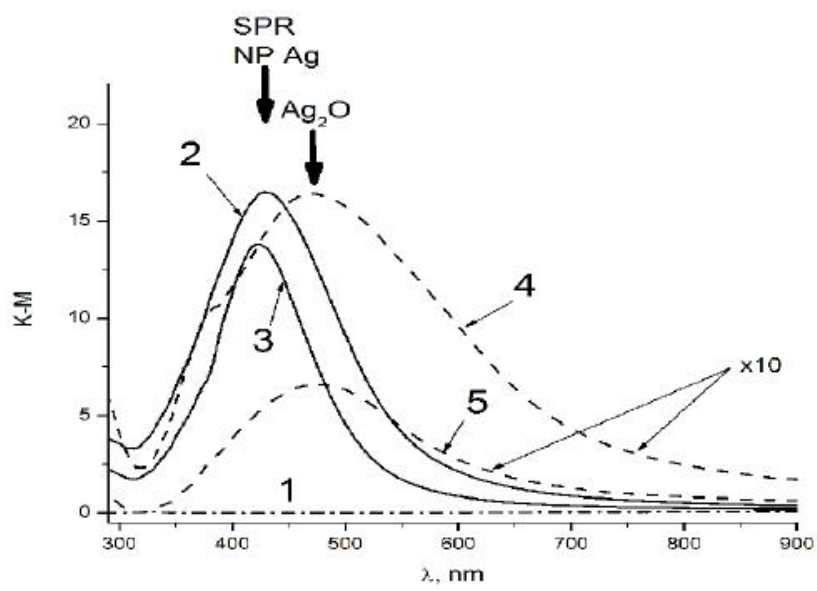

Figure 1: DRS of pure fabric (1), heat-treated fabrics with silver NPs obtained from $\mathrm{AgNO}_{3}$ impregnation solutions $1 \cdot 10^{-2}$ (2) and $1 \cdot 10^{-3}$ (3) $\mathrm{mol} / \mathrm{L}$, and air dried tissues containing silver ions obtained from solutions $1 \cdot 10^{-2}(4)$ and $1 \cdot 10^{-3}(5) \mathrm{mol} / \mathrm{L}$.

$\mathrm{Ag} / \mathrm{Cu}$ NPs on the tissue' surface with the average size $20-60 \mathrm{~nm}$ are shown on the SEM image (Figure. 3). NPs are firmly held on the surface, not losing the activity even after a washing. Washout solutions do not contain tracks of silver or copper.

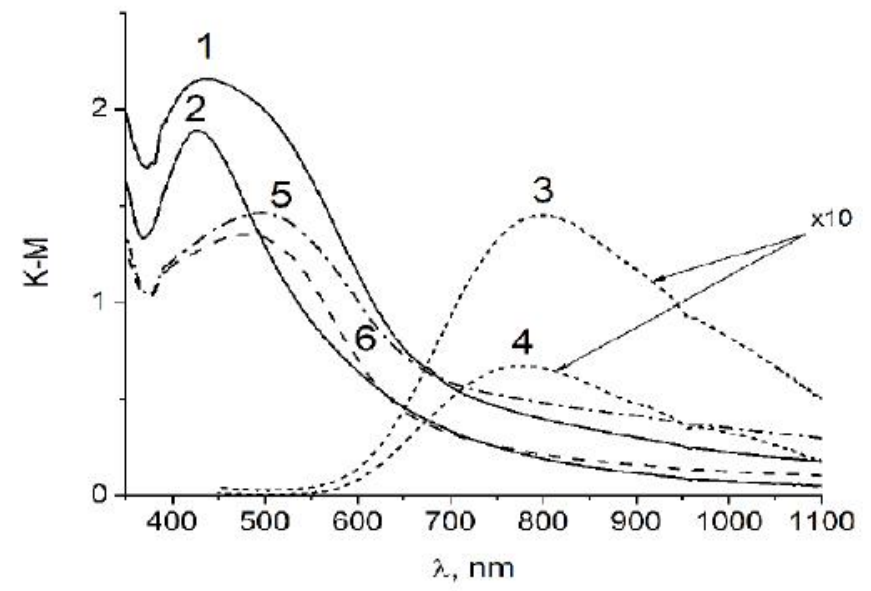

Figure 2: DRS of the $\mathrm{Ag} / \mathrm{Cu}$ fabrics, obtained from initial solutions $1 \cdot 10^{-1}(1)$ and $1 \cdot 10^{-2}(2) \mathrm{mol} / \mathrm{L}$ (heat-treated fabrics), $\mathrm{Cu} /$ tissue obtained from initial solutions $1 \cdot 10^{-1}(3)$ and $1 \cdot 10^{-2}(4) \mathrm{mol} / \mathrm{L}$ (heat-treated) and fabrics with the composition of $\mathrm{Ag}^{+} / \mathrm{Cu}^{2+}$ without heat treatment (airdried), obtained from impregnation solutions $1 \cdot 10^{-1}(5)$ and $1 \cdot 10^{-2}(6)$ $\mathrm{mol} / \mathrm{L}$.

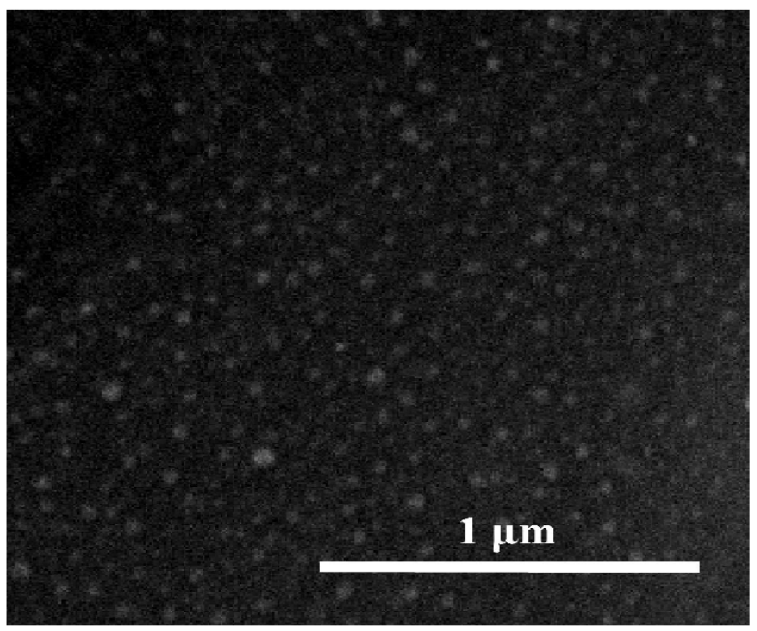

Figure 3: SEM-image of $\mathrm{Ag} / \mathrm{Cu} \mathrm{NPs}$ on the tissue's surface.

The electrical resistance of all dry non-modified and modified with NPs fabrics is more than $4 \mathrm{MOhm}$. It should confirm that metal particles firmly hold out on fabric as individual clusters separated from each other. It should be noted that the surface of the fabrics becomes hydrophobic after modification by metallic NPs. After wetting of the fabric with double-distilled water or with $\mathrm{KNO}_{3}$ solution the resistance of the modified samples reduced sharply. Typical results are shown in the Table 1. On an air-dried tissue surface only ions of metal are located, in this case samples demonstrate purely ionic conductivity since the fabric retains some moisture. Metal ions are generated on the surface of NPs which leads to increase of the conductivity of the tested system in water. Especially notable decreasing of the electrical resistance was observed after the treatment of the fabric with electrolyte solution as a result of significant contribution of ionic conductivity introduces $\mathrm{KNO}_{3}$ to the overall electrical conductivity. We can suggest that in the case of NPs/tissue samples the mechanism of mixed electron - ionic conductivity takes place. This issue requires separate investigation.

It should be noted that electrical conductivity of samples depends on the concentrations of metal ions. It means that the conductivity can be controlled by the content of the particles 
on the surface. The obtained results testify the migration of ions and atoms of metal on the surface of fabric during the contact with a biological environment. It is known that Ag NPs are the original deposited form of silver ions, constantly generating and eliminating from the NPs surface in the process of binding to biological substrates. Thus locally (near the surface of the particles) high ion concentrations, harmful to germs are generating. Low bactericidal activity of $\mathrm{Cu}$ /textile (without silver in composition) is related to blocking the copper (ions) by the sulfhydryl groups of proteins on the bacteria surfaces that is confirmed in a number of publications about co-operating of copper with an amino acid cystein (see e.g. Ref ${ }^{[14]}$ ). Cu NPs lost their bactericide effect due to the formation of stable thiol complexes and inaccessibility of copper for bacteria ${ }^{[17]}$. Strong binding of copper ions with cysteine as a consequence of their bactericidal inactivation is shown $\mathrm{in}^{[18]}$.

Table 1: Comparison of electric resistance of modified tissues wetted by distilled water and $0.1 \mathrm{M} \mathrm{KNO} 3$ solution. Metal atoms ratio in the cotton compositions with silver and copper is $1: 1$, molar concentration of metal salts in the solution of impregnation is $1 \cdot 10^{-1} \mathrm{~mol} / \mathrm{L}$ for each of the salt.

\begin{tabular}{|c|c|c|c|}
\hline Samples & $\begin{array}{l}\text { Electric resis- } \\
\text { tance, MOhm }\end{array}$ & $\begin{array}{l}\text { Electric resis- } \\
\text { tance, } \mathrm{\kappa Ohm} \\
\pm 5 \mathrm{KOhm}\end{array}$ & $\begin{array}{l}\text { Electric resis- } \\
\text { tance, } \mathrm{\kappa Ohm} \\
\pm 2 \mathrm{\kappa Ohm}\end{array}$ \\
\hline $\begin{array}{l}\text { Tissues con- } \\
\text { tained metal } \\
\text { as NPs or ions }\end{array}$ & Dry & $\begin{array}{l}\text { wetted with } \\
\text { bidistilled } \\
\text { water }\end{array}$ & $\begin{array}{l}\text { wetted with } \\
0.1 \mathrm{M} \text { solution } \\
\text { of } \mathrm{KNO}_{3}\end{array}$ \\
\hline $\mathrm{Ag} / \mathrm{Cu}$ NPs & $>4$ & 320 & 55 \\
\hline Cu NPs & $>4$ & 100 & 20 \\
\hline Ag NPs & $>4$ & 100 & 8 \\
\hline $\mathrm{Ag}^{+} / \mathrm{Cu}^{2+}$ ions & $>4$ & 10 & 7,5 \\
\hline $\mathrm{Cu}^{2+}$ ions & $>4$ & 30 & 30 \\
\hline $\mathbf{A g}^{+}$ions & $>4$ & 90 & 40 \\
\hline blank & $>4$ & 2600 & 460 \\
\hline
\end{tabular}

Ionizing potential of Ag NPs with the sizes of 1 - 2 $\mathrm{nm}$ is lower on $1,5 \mathrm{eV}$ as compared to bulk silver, i.e., from the developed surface of NPs the ions of silver are considerably easier generated ${ }^{[19]}$. We suppose that in $\mathrm{Ag} / \mathrm{Cu}$ composition the $\mathrm{Ag}$ NPs protect $\mathrm{Cu}$ particles from direct interaction with sulphur groups on the surface of bacteria thereby facilitate the release of copper ions/atoms into the biological environment. Due to substantial distinction of oxidizing potentials $-0.337 \mathrm{~V}$ for copper and $0.799 \mathrm{~V}$ for silver, copper facilitates the reduction of silver ions to NPs. We revealed $\mathrm{in}^{[11]}$ that fabrics doped with bimetallic composite $\mathrm{Ag} / \mathrm{Cu}$ have pronounced antimycotic properties also in comparison with individual metal/fabric materials. In gener$\mathrm{al}$, the nature of the interaction in $\mathrm{Ag} / \mathrm{Cu} /$ cotton system is quite complex and requires further research.

Content of $\mathrm{Ag}$ and $\mathrm{Cu}$ of the surface of ironed fabric calculated on results of the method of flaming atomic-absorbing spectroscopy is app. $2,4 \times 10^{17}$ gram-atom $/ \mathrm{cm}^{2}$ for each metal that corresponds to the initial concentrations of metal salts used for the impregnation of fabrics. In case of air-dried fabrics the amount of $\mathrm{Ag}^{+}$and $\mathrm{Cu}^{2+}$ ions on the surface is two times less for each ion probably due to the fact that part of the solution remains on the paper substrate during drying.

Since washing of NPs from fabrics in solution is not fixed during 24 - 48 hours, it is possible to assert that the process of destruction of bacteria takes place directly on the surface of fabric. Antimicrobial properties of fabrics modified with Ag NPs are confirmed in experiments with gram-negative microorganisms - colli bacillus (E. coli) and $P$. aerogin and gram-positive microorganism - Staphylococcus aurous (S. aurous) (see Table. 2). Zone of delay of bacteria population for the fabrics contained $\mathrm{Ag}$ and $\mathrm{Ag} / \mathrm{Cu}$ ions (no heat treatment) is similar with one for the heat-treated fabrics. Thus the ions of silver in water solution demonstrate insignificant bactericidal activity in relation to the indicated microorganisms, and the ions of copper appear quite inactive. We assume that reduction of the ions of silver and copper to NPs begins directly during adsorption on cotton, and heat treatment of fabric at $220^{\circ} \mathrm{C}$ assists the rapid passing of this process with formation of NPs. As it was mentioned above, NPs and ions of metals firmly hold out in the structure of fabrics and not washed at a contact with water, even after a washing in hot water.

Table 2: Antimicrobial activity of tissue samples modified with Ag and $\mathrm{Ag} / \mathrm{Cu} \mathrm{Nps}$.

\begin{tabular}{|c|c|c|c|c|}
\hline \multirow[t]{2}{*}{ Sample } & \multirow{2}{*}{$\begin{array}{l}\text { The molar con- } \\
\text { centration of the } \\
\text { impregnation solu- } \\
\text { tion of tissue mol/L }\end{array}$} & \multicolumn{3}{|c|}{$\begin{array}{l}\text { Microbial growth inhibition } \\
\text { zone, } \mathbf{m m}\end{array}$} \\
\hline & & S. aureus & P. aerugin & E. coli \\
\hline $\begin{array}{l}\text { Tissue } \\
\text { (control) }\end{array}$ & - & 0 & 0 & 0 \\
\hline \multirow{4}{*}{ Ag/Tissue } & 0,1000 & 2,0 & 2,0 & 2,0 \\
\hline & 0,0100 & 2,0 & 2,0 & 4,0 \\
\hline & 0,0010 & 2,0 & 1,0 & 3,0 \\
\hline & 0,0001 & 0 & 0 & 0 \\
\hline \multirow{4}{*}{$\begin{array}{l}\mathrm{Ag} / \mathrm{Cu} / \mathrm{Tis}- \\
\text { sue }\end{array}$} & 0,1000 & 4,0 & 3,0 & 5,0 \\
\hline & 0,0100 & 5,0 & 3,0 & 2,5 \\
\hline & 0,0010 & 3,0 & 3,0 & 1,0 \\
\hline & 0,0001 & 1,0 & 0,0 & 0,0 \\
\hline \multirow{3}{*}{$\mathbf{A g}^{+} /$Tissue } & 0,1000 & 3,0 & 4,0 & 4,0 \\
\hline & 0,0100 & 4,0 & 2,0 & 4,0 \\
\hline & 0,0010 & 2,0 & 2,0 & 3,0 \\
\hline $\begin{array}{l}\mathrm{Ag}^{+} / \mathrm{Cu}^{2+} / \\
\text { Tissue }\end{array}$ & 0,1000 & 5,0 & 4,0 & 5,0 \\
\hline
\end{tabular}

Table 3 shows the biocide properties of tissues modified with metals before and after 1 wash cycle in the washing machine by detergent "Gala" at $60^{\circ} \mathrm{C}$ for 30 minutes in fast mode washing. The $\mathrm{Ag} / \mathrm{Cu}$ modified fabrics both before and after washing had greater antimicrobial activity comparing with samples containing only silver. A similar trend was observed in the study of antitumor properties of bimetallic nanoparticles Ag/ $\mathrm{Au}^{[20]}$ with more pronounced antibacterial properties compared to the monometallic ones. 
Table 3: Comparison of antimicrobial activity of tissues modified with $\mathrm{Ag}$ and $\mathrm{Ag} / \mathrm{Cu}$ NPs before and after washing.

\begin{tabular}{|c|c|c|c|c|c|c|c|}
\hline \multirow{3}{*}{ Sample } & \multirow{3}{*}{$\begin{array}{l}\text { The molar } \\
\text { concentra- } \\
\text { tion of the } \\
\text { impregnation } \\
\text { solution of } \\
\text { tissue mol/L }\end{array}$} & \multicolumn{6}{|c|}{$\begin{array}{c}\text { Microbial growth inhibition zone, } \\
\text { mm }\end{array}$} \\
\hline & & \multicolumn{2}{|c|}{ S. aureus } & \multicolumn{2}{|c|}{ P. aerugin } & \multicolumn{2}{|c|}{ E. coli } \\
\hline & & : & 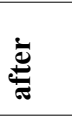 & $\begin{array}{l}0 \\
\\
\end{array}$ & 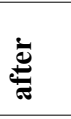 & 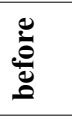 & 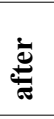 \\
\hline $\begin{array}{l}\text { Tissue } \\
\text { (control) }\end{array}$ & - & 0 & 0 & 0 & 0 & 0 & 0 \\
\hline Ag/Tissue & 0,1 & 2,0 & 2,0 & 3,0 & 2,0 & 2,0 & 2,0 \\
\hline $\begin{array}{l}\mathrm{Ag} / \mathrm{Cu} / \\
\text { Tissue }\end{array}$ & 0,1 & 7,0 & 6,0 & 4,0 & 4,0 & 3 & 2,5 \\
\hline
\end{tabular}

\section{Conclusion}

Bactericide cotton modified with bimetallic Ag/Cu NPs is produced by fast and economical method and characterized with optical spectroscopy, electrical conductivity (increases dramatically after wetting), SEM and flame atomic absorption spectroscopy (quantification of the ratio of $\mathrm{Ag}: \mathrm{Cu}$ ) methods. The resulting materials have high bactericidal activity against the bacteria Staphylococcus aurous, Pseudomonas aeroginosa and Escherichia coli even after storage for 18 weeks under normal conditions and after machine washing. This allows us to recommend them for external use in medicine as disposable (wound dressings) and reusable materials (textiles in hospitals, military clothing etc).

\section{References}

[1] Taubes, G. The bacteria fight back. (2008) Science 321(5887): 356361.

[2] Huh, A., Kwon, Y. "Nanoantibiotics": a new paradigm for treating infectious diseases using nanomaterials in the antibiotics resistant era. (2011) J Control Release 156(2): 128-145.

[3] Lansdown, A.B. Silver in health care: antimicrobial effects and safety in use. (2006) Current Probl Dermatol 33:17-34.

[4] Ruparelia, J.P., Chatterijee, A.K., Duttagupta, S.P. et al. Strain specificity in antimicrobial activity of silver and copper nanoparticles. (2008) Acta Biomater 4(3): 707-716.

[5] Esteban-Tejeda, L., Malpartida, F., Esteban-Cubillo, A., Pecharroman, C., et al. Antibacterial and antifungal activity of a soda-lime glass containing copper nanoparticles. (2009) Nanotechnol 20(50): 505701.
[6] Usman, M., Zowalaty, M., Shameli, K., et al. Synthesis, characterization, and antimicrobial properties of copper nanoparticles. (2013) Int J Nanomed 8: 4467-4479.

[7] Marambio-Jones, C., Hoek, E. A review of the antibacterial effects of silver nanomaterials and potential implications for human health and the environment. (2010) J Nanopart Res 12(5): 1531-1551.

[8] Minoshima, M., Lu, Y., Kimura, T., et al. Comparison of the antiviral effect of solid-state copper and silver compounds. (2016) J Hazard Mater (312): 1-7.

[9] Khan, A.U., Wei, Y., Khan, Z.U.H., et al. Electrochemical and Antioxidant Properties of Biogenic Silver Nanoparticles. (2015) Int J Electrochem Sci 10(2015): 7905-7916.

[10] Wasif, A.I., Landage, S.M., Dhuppe, P.U. Application of nanosilver on textiles synthesized using chemical reduction methods. (2014) Int J Adv Resear Engine Appl Sci 3(7): 45-53.

[11] Eremenko, A.M., Petrik, I.S., Smirnova, N.P., et al. Antibacterial and Antimycotic Activity of Cotton Fabrics, Impregnated with Silver and Binary Silver/Copper Nanoparticles. (2016) Nanoscale Res Lett 11(1): 28.

[12] Eremenko, A., Smirnova, N., Petrik, I., et al. A method for producing antibacterial material based on nanosized silver. (2015) US patent 101592.

[13] Eremenko, A., Smirnova, N., Petrik, I., et al. A method for producing antibacterial material based on nanosized composite silver and ,copper. US patent 102532 .

[14] Pei, F., Wu, S., Wang, G., et al. Electronic and Optical Properties of Noble Metal Oxides M2O ( $=\mathrm{Cu}, \mathrm{Ag}$ and $\mathrm{Au})$ : First-principles Study. (2009) J Korean Physical Soc 55(3): 1243-1249.

[15] Smith, J.G., Jain, P. The combined kinetics of cysteine physisorption, chemisorption and self-assembly averaged over the entire nanoparticle. (2016) Phys Chem Chem Phys 18: 23990-23997.

[16] Ren, G., Hu, D., Cheng, E.W., et al. Characterization of copper oxide nanoparticles for antimicrobial applications. (2009) Int J Antimicrob Agents 33(6): 587-590.

[17] Ahmed, M., Iqbal, M., Tahir, N., et al. Solvent free Synthesis of Cu(II) Cysteine Complexes. (2011) World Appl Sci J 14(2): 210-214.

[18] Petrik, I.S., Eremenko, A.M., Smirnova ,N.P., et al. Synthesis and stabilization of $\mathrm{Cu}$ nanoparticles in aqueous solutions and their bactericidal activity. (2014) Chem Physics Technol Surface 5(1): 74-81.

[19] Blagitko, E.M., Burmistrov, V.A., Kolesnikov, A.P., et al. Silver in medicine. Novosibirsk: Nauka (2004). 254 p. (Rus).

[20] Shmarakov, I., Marchenko, M., Mukha, Y ., et al. Cyto- and genotoxic influence of colloidal ag and au nanopreparations on primary cell cultures. (2010) Biological Sys 2(4): 13-20.
Ommega Online Publisher

Journal of Analytical, Bioanalytical and Separation Techniques

Short Title : J Anal Bioanal Sep Tech
E-mail: analyticaltech@ommegaonline.com website: www.ommegaonline.org 